\title{
Karakteristik Mutu Organoleptik Olahan Coklat Dengan Lama Fermentasi Yang Berbeda Pada Biji Kakao Lindak (Theobroma cacao L.)
}

\author{
${ }^{1}$ Ridawati Marpaung dan ${ }^{2}$ Siti Nurlina Putri \\ ${ }^{1}$ Program Studi Agroteknologi Fakultas Pertanian Universitas Batanghari \\ ${ }^{2}$ Alumni Program Studi Agroteknologi, Fakultas Pertanian Universitas Batanghari \\ Jl. Slamet Riyadi, Broni Jambi, 36122. Telp. +62741 60103 \\ 1e-mail korenspondensi : marpaungridawati@gmail.com
}

\begin{abstract}
The aim of this study was to determine the organoleptic quality characteristics of processed chocolate with different fermentation times on the cocoa beans. Fermentation up to drying of cocoa beans is carried out in RT 12 Kelurahan Sungai Asam, Pasar Jambi district and the processing of chocolate and organoleptic analysis of chocolate are carried out at the Laboratory of the University of Batanghari Jambi from May to July 2019. The study was designed using a completely randomized design (CRD), with treatment different fermentation time, as follows: $F 0=$ not fermented, $F 1=2$ days fermentation, $F 2=4$ days fermentation, $F 3=6$ days fermentation, and $F 4=8$ days fermentation. Each treatment was repeated 3 times so that there were 15 units of experiment, each unit of experiment was $1 \mathrm{~kg}$ of cocoa beans, so that the total number of cocoa beans was $15 \mathrm{~kg}$. Variables observed were color, flavor, taste, bitterness, preference for chocolate, $\mathrm{pH}$ and moisture content of dried cocoa beans. The results showed that different fermentation time significantly affected the organoleptic quality of color, flavor, taste, preferences and $\mathrm{pH}$ and water content of dried cocoa beans, but not significantly different from bitterness. The highest assessment of color, flavor, taste, bitterness and likeness is found in the 6-days and 8-days fermentation treatment.
\end{abstract}

Keywords: fermentation, bulk cocoa, chocolate organoleptic quality.

Abstrak. Penelitian ini bertujuan untuk mengetahui karakteristik mutu organoleptik olahan coklat dengan lama fermentasi yang berbeda pada biji kakao lindak. Fermentasi hingga pengeringan biji kakao dilaksanakan di RT 12 Kelurahan Sungai Asam Kecamatan Pasar Jambi dan proses pengolahan coklat serta analisis organoleptik olahan coklat dilaksanakan di Laboratorium Dasar Universitas Batanghari Jambi mulai bulan Mei sampai Juli 2019. Penelitian dirancang menggunakan rancangan acak lengkap (RAL), dengan perlakuan lama fermentasi yang berbeda, sebagai berikut: F0 = tidak difermentasi, $\mathrm{F} 1=$ fermentasi 2 hari, F2 = fermentasi 4 hari, F3 = fermentasi 6 hari, dan F4 = fermentasi 8 hari. Setiap perlakuan diulang 3 kali sehingga terdapat 15 unit percobaan, setiap unit percobaan terdapat $1 \mathrm{~kg}$ biji kakao,sehingga jumlah keseluruhan biji kakao adalah $15 \mathrm{~kg}$. Peubah yang diamati adalah warna, aroma, cita rasa, kepahitan, kesukaan pada coklat, $\mathrm{pH}$ dan kadar air biji kakao kering. Hasil penelitian menunjukkan bahwa lama fermentasi yang berbeda berpengaruh nyata terhadap mutu organoleptik warna, aroma, cita rasa, kesukaan serta $\mathrm{pH}$ dan kadar air biji kakao kering, tetapi berbeda tidak nyata terhadap kepahitan. Penilaian tertinggi terhadap warna, aroma, cita rasa, kepahitan dan kesukaan terdapat pada perlakuan lama fermentasi 6 hari dan 8 hari.

Kata kunci : fermentasi, kakao lindak, mutu organoleptik coklat.

\section{PENDAHULUAN}

Kakao merupakan salah satu komoditas andalan perkebunan yang peranannya cukup penting bagi perekonomian nasional. Kakao juga telah lama menjadi salah satu komoditi ekspor unggulan Indonesia, yang memiliki kontribusi yang cukup besar dalam menghasilkan devisa negara. Indonesia sebagai produsen kakao terbesar ketiga dunia setelah Pantai Gading dan Ghana. Indonesia berpeluang menjadi produsen utama kakao mengingat letak geografis wilayah Indonesia yang berada di garis khatulistiwa sebagian besar cocok bagi pengembangan kakao (Suryani, 2013). 
Biji Kakao adalah bahan utama dalam pembuatan coklat yang merupakan bahan dalam pembuatan kue, es krim, makanan ringan, susu dan lain-lainnya. Coklat memiliki karakter rasa yang sangat gurih dan memiliki aroma yang khas. Cokelat juga telah menjadi salah satu rasa yang paling populer di dunia, mengandung alkaloid-alkaloid seperti teobromin, fenetilamina, dan anandamida, yang memiliki efek fisiologis untuk tubuh yang banyak dihubungkan dengan tingkat serotonin dalam otak dan memiliki sifat afrodisia sehingga dapat menimbulkan perasaan senang bagi yang mengkonsumsinya. Coklat juga bisa diberikan sebagai hadiah atau bingkisan dengan bentuk dan rasa yang berbeda, sering digunakan sebagai ungkapan terima kasih atau perhatian sebagai ungkapan rasa cinta (Nuraeni, 2011).

Fermentasi merupakan salah satu tahap penting dalam pengolahan biji kakao untuk menghasilkan senyawa pembentuk warna, aroma dan cita-rasa yang khas. Senyawa yang membentuk cita rasa adalah polifenol, theobromin dan asam-asam organik. sedangkan komponen prekursor aroma terbentuk dari hasil hidrolisis protein dan sukrosa biji kakao (Putra, 2013).

Cita rasa termasuk dalam sifat-sifat organoleptik yang dapat diukur dengan indra dan dapat dipengaruhi oleh sifat fisik, kimiawi, dan faktor-faktor agronomi serta teknologi. Penilaian kualitas organoleptik bergantung pada evaluasi sensorik. Penilaian kualitas organoleptik coklat membutuhkan latihan terutama aroma dari coklat yang merupakan kombinasi multi aromatik pada coklat ( Leroy, 2006 ).

Fermentasi dilakukan untuk memperoleh biji kakao kering yang bermutu baik dan memiliki aroma serta cita rasa khas coklat. Cita rasa khas coklat ditentukan oleh fermentasi dan penyangraian. Biji yang kurang fermentasi ditandai dengan warna ungu, bertekstur pejal, rasanya pahit dan sepat, sedangkan fermentasi yang berlebihan akan manghasilkan biji yang mudah pecah, berwarna coklat tua, cita rasa coklat kurang dan berbau apik. Fermentasi biji kakao akan menghasilkan prekursor cita rasa, mencokelathitamkan warna biji, mengurangi rasa pahit, asam, manis dan aroma bunga, meningkatkan aroma kakao dan kacang (nutty), dan mengeraskan kulit biji menjadi seperti tempurung. Biji yang tidak difermentasi tidak akan memiliki senyawa prekursor tersebut sehingga cita rasa dan mutu biji sangat rendah (Karmayanto, E., dkk, 2010; Rahardi, 2011).

Proses fermentasi harus dikendalikan agar tidak berlebihan yang dapat menimbulkan cita rasa yang terbentuk berkualitas kurang baik karena timbulnya rasa asam akibat pembusukan oleh mikroorganisme. Jika waktu fermentasi kurang atau tidak sempurna, maka cita rasa khas coklat tidak terbentuk dan seringkali menghasilkan cita rasa ikutan tidak dikehendaki, seperti rasa asam, pahit, dan kelat (Indrayati, 2013).

Waktu fermentasi yang diterapkan oleh negara-negara penghasil kakao memiliki variasi sangat besar, mulai dari 1,5-10 hari. Perbedaan utama terjadi karena varietas kakao, biji kakao criollo difermentasi selama 2-3 hari dan biji forestero 6-8 hari. Waktu fermentasi juga bergantung pada metode fermentasi yang diterapkan, fermentasi dalam kotak pada umumnya selama 6 hari atau 144 jam, tetapi dapat dipersingkat maupun diperpanjang bergantung pada kondisi dan proses fermentasi. Fermentasi tumpukan biasanya dilakukan selama 6 hari, sementara waktu fermentasi untuk metode tray (penampungan atau kotak) dapat dilakukan selama 3-5 hari.

Biasanya proses fermentasi pada biji kakao akan berlangsung secara sempurna dengan lama fermentasi 5-8 hari bergantung pada varietas kakaonya. Jika fermentasi yang dilakukan kurang atau tidak sempurna, selain cita rasa khas cokelat tidak terbentuk, juga seringkali dihasilkan citarasa ikutan yang tidak dikehendaki, seperti rasa masam, pahit, dan kelat.

Uji organoleptik merupakan pengujian terhadap bahan makanan berdasarkan kesukaan dan kemauan untuk mempergunakan suatu produk. Uji organoleptik atau uji indera atau uji sensori merupakan cara pengujian dengan menggunakan indera manusia sebagai alat utama untuk pengukuran daya penerimaan terhadap produk. Pengujian organoleptik mempunyai peranan penting dalam penerapan mutu. Pengujian organoleptik dapat memberikan indikasi kemunduran mutu dan kerusakan lainnya dari produk. Syaratsyarat yang harus ada dalam uji organoleptik adalah adanya contoh (sampel), panelis, dan pernyataan respon yang jujur. (Putri, 2011).

Evaluasi sensori merupakan suatu metode yang dilakukan oleh manusia menggunkan panca indera manusia yaitu mata, hidung, mulut, tangan dan juga telinga. Melalui lima panca indera dasar ini, kita dapat 
menilai atribut sensori suatu produk seperti warna, rupa, bentuk, rasa dan tekstur. Bidang penilaian sensori memerlukan subjek untuk menilai produk. Subjek ini kemudian disebut sebagai konsumen dan panelis laboraturium. Setiap pemakaian panelis sangat tergantung pada metode yang digunakan dalam sebuah penelitian (Abdullah, 2005).

Analisis deskriptif kualitatif (ADK) merupakan teknik penilaian sensori yang mencirikan tanggapan atribut-atribut sensori dalam bentuk kuantitatif. Metode ADK mampu memberikan uraian perkataan yang cukup baik semua ciri sensori produk. Ini meliputi produk yang telah ada (masih dan sedang berada dipasaran), ramuan, ide atau produk baru yang masih belum ada saingan dan ADK menggunakan panelis terlatih (Cardelli, 2001).

\section{METODE PENELITIAN}

Pelaksanaan fermentasi hingga pengeringan biji kakao dilaksanakan di RT 12 Kelurahan Sungai Asam Kecamatan Pasar Jambi, sedangkan proses pengolahan coklat serta analisis organoleptik olahan coklat dilaksanakan di Laboratorium Dasar Universitas Batanghari Jambi. Penelitian dilakukan pada bulan Mei sampai Juli 2019.

Bahan-bahan yang digunakan dalam penelitian ini adalah buah kakao lindak, aquadest serta bahan pencampur olahan coklat yaitu susu kental manis. Sedangkan alat yang akan digunakan antara lain polybag ukuran 5kg, pH meter, pisau, wadah, daun pisang, kompor gas, kuali, spatula, alat penggiling (blender), sendok takar, beaker glass dan gradasi warna coklat.

Penelitian dirancang menggunakan rancangan acak lengkap (RAL), dengan perlakuan lama fermentasi yang berbeda, sebagai berikut: F0 = tidak difermentasi, F1 = fermentasi 2 hari, F2 = fermentasi 4 hari, F3 = fermentasi 6 hari, dan F4 = fermentasi 8 hari. Setiap perlakuan dilakukan pengulangan sebanyak 3 kali sehingga terdapat 15 unit percobaan, setiap unit percobaan terdapat $1 \mathrm{~kg}$ biji kakao,sehingga jumlah keseluruhan biji kakao adalah $15 \mathrm{~kg}$.

Tahapan pelaksanaan penelitian meliputi pemanenan, pemecahan buah, fermentasi, pencucian, penjemuran, pengolahan biji kakao, serta pelaksanaan uji organoleptik.

Peubah utama yang diamati adalah warna coklat, aroma coklat, cita rasa coklat, kepahitan, kesukaan . Pengujian dan penilaian pada setiap peubah yang diamati pada olahan coklat dilakukan dengan menggunakan panduan kuisioner. Pengamatan sekunder dalam penelitian ini adalah pengukuran $\mathrm{pH}$ biji kakao kering, dan persentase biji berkecambah

Untuk melihat pengaruh lama fermentasi yang berbeda, data hasil pengamatan peubah warna, aroma, cita rasa, kepahitan dan kesukaan dilakukan dengan uji persepsi dengan skala Linkert 5 skala, sedangkan hasil pengamatan $\mathrm{pH}$ biji kering kakao dan persentase biji berkecambah dilakukan uji $\mathrm{F}$ pada taraf $\alpha 5 \%$, kemudian dilanjutkan dengan uji DNMRT pada taraf $\alpha 5 \%$. 


\section{Hasil Pengamatan \\ Warna Coklat}

Warna merupakan parameter utama yang menentukan tingkat ketertarikan konsumen terhadap hasil olahan coklat. Dari hasil analisis dan uji DNMRT menunjukkan bahwa lama fermentasi yang berbeda pada biji kakao lindak berpengaruh nyata terhadap warna coklat. Skor nilai warna coklat dengan lama fermentasi yang berbeda dapat dilihat pada Tabel 1 berikut ini.

Tabel 1. Skor nilai warna coklat dengan lama fermentasi yang berbeda.

\begin{tabular}{ccc}
\hline Perlakuan & Skor & Warna Coklat* \\
\hline Tanpa fermentasi & $57,1 \mathrm{a}$ & Coklat kehitaman \\
Fermentasi 4 hari & $58,8 \mathrm{a}$ & Coklat kehitaman \\
Fermentasi 2 hari & $59,4 \mathrm{a}$ & Coklat kehitaman \\
Fermentasi 8 hari & $70,5 \mathrm{~b}$ & Coklat \\
Fermentasi 6 hari & $71,6 \mathrm{~b}$ & Coklat \\
\hline
\end{tabular}

Keterangan : Angka-angka yang diikuti huruf kecil yang sama berbeda tidak nyata menurut uji DNMRT taraf $=\alpha 5 \%$

* : Interpretasi skor Skala Likert 5 skala

Dari Tabel 1 dapat dilihat bahwa warna coklat dengan lama fermentasi 2, 4 hari dan tanpa fermentasi menunjukkan hasil berbeda tidak nyata. Perlakuan fermentasi 8 dan 6 hari juga menunjukkan hasil berbeda tidak nyata, tetapi berbeda nyata bila dibandingkan dengan perlakuan tanpa fermentasi, fermentasi 2 dan 4 hari. Hasil uji interpretasi skor skala Linkert 5 skala, warna coklat pada perlakuan fermentasi 6 dan 8 hari menunjukkan warna coklat, sedangkan fermentasi 4, 2 hari dan tanpa fermentasi menunjukkan warna coklat kehitaman.

\section{Aroma Coklat}

Aroma merupakan salah satu faktor terpenting bagi konsumen dalam memilih coklat yang disukai. Dari hasil analisis dan uji DNMRT menunjukkan bahwa lama fermentasi yang berbeda pada biji kakao lindak berpengaruh nyata terhadap aroma coklat. Skor nilai aroma coklat dengan lama waktu fermentasi yang berbeda dapat dilihat pada Tabel 2 berikut ini.

Tabel 2. Skor nilai aroma coklat dengan lama fermentasi yang berbeda.

\begin{tabular}{ccc}
\hline Perlakuan & Skor & Aroma Coklat* \\
\hline Tanpa fermentasi & $52,2 \mathrm{a}$ & Agak disukai \\
Fermentasi 2 hari & $58,8 \mathrm{~b}$ & Agak disukai \\
Fermentasi 4 hari & $63,8 \mathrm{c}$ & Agak disukai \\
Fermentasi 8 hari & $72,2 \mathrm{~d}$ & Disukai \\
Fermentasi 6 hari & $74,9 \mathrm{~d}$ & Disukai \\
\hline
\end{tabular}

Keterangan : Angka-angka yang diikuti huruf kecil yang sama berbeda tidak nyata menurut uji DNMRT taraf $=\alpha 5 \%$

* : Interpretasi skor Skala Likert 5 skala

Dari Tabel 2 dapat dilihat bahwa aroma coklat dengan perlakuan lama fermentasi 2, 4 dan tanpa fermentasi menunjukkan hasil berbeda nyata, sedangkan perlakuan lama fermentasi 8 dan 6 hari menunjukkan hasil berbeda tidak nyata. Hasil uji interpretasi skor skala Linkert 5, skala aroma coklat yang disukai panelis yaitu pada perlakuan fermentasi 8, dan 6 hari, sedangkan fermentasi 2, 4 hari dan tanpa fermentasi menunjukan nilai agak disukai.

\section{Cita Rasa Coklat}

Cita rasa coklat sangat berpengaruh terhadap kesukaan konsumen. Dari hasil analisis dan uji DNMRT menunjukkan bahwa dengan lama fermentasi yang berbeda pada biji kakao lindak berpengaruh nyata terhadap cita rasa coklat. Skor nilai cita rasa coklat pada beberapa waktu fermentasi yang berbeda dapat dilihat pada Tabel 3 berikut ini. 
Ridawati Marpaung dan Siti Nurlina Putri. Karakteristik Mutu Organoleptik Olahan Coklat Dengan Lama Fermentasi Yang Berbeda Pada Biji Kakao Lindak (Theobroma Cacao L.)

Tabel 3. Skor nilai cita rasa coklat dengan lama fermentasi yang berbeda.

\begin{tabular}{ccc}
\hline Perlakuan & Skor & Cita Rasa Coklat* \\
\hline Fermentasi 4 hari & $49,9 \mathrm{a}$ & Agak disukai \\
Fermentasi 2 hari & $52,7 \mathrm{ab}$ & Agak disukai \\
Tanpa fermentasi & $58,3 \mathrm{abc}$ & Agak disukai \\
Fermentasi 8 hari & $61,6 \mathrm{bc}$ & Disukai \\
Fermentasi 6 hari & $68,8 \mathrm{c}$ & Disukai \\
\hline
\end{tabular}

Keterangan : Angka-angka yang diikuti huruf kecil yang sama berbeda tidak nyata menurut uji DNMRT taraf $=\alpha 5 \%$

* : Interpretasi skor Skala Likert 5 skala

Dari Tabel 3 dapat dilihat bahwa cita rasa coklat dengan lama fermentasi 4, 2 hari dan tanpa fermentasi menunjukkan hasil berbeda tidak nyata. Perlakuan lama fermentasi 2, 8, hari dan tanpa fermentasi juga menunjukan hasil tidak berbeda nyata. Selanjutnya untuk perlakuan fermentasi 8, 6 hari dan tanpa fermentasi juga menunjukkan hasil berbeda tidak nyata, tetapi perlakuan fermentasi 6 hari berbeda nyata dengan fermentasi 4 hari. Hasil uji interpretasi skor skala Linkert 5, skala cita rasa coklat yang disukai panelis yaitu pada perlakuan fermentasi 8 dan 6 hari, sedangkan fermentasi 4, 2 hari dan tanpa fermentasi menunjukan nilai agak disukai.

\section{Kepahitan Coklat}

Dari hasil analisis dan uji DNMRT menunjukkan bahwa dengan lama waktu fermentasi yang berbeda pada biji kakao lindak tidak berpengaruh nyata terhadap kepahitan coklat. Skor nilai cita rasa coklat pada beberapa waktu fermentasi yang berbeda dapat dilihat pada Tabel 4 berikut ini.

Tabel 4. Skor nilai kepahitan coklat dengan lama fermentasi yang berbeda.

\begin{tabular}{ccc}
\hline Perlakuan & Skor & Kepahitan Coklat* \\
\hline Fermentasi 4 hari & $55,5 \mathrm{a}$ & Pahit \\
Fermentasi 8 hari & $56,6 \mathrm{a}$ & Pahit \\
Tanpa fermentasi & $64,9 \mathrm{a}$ & Agak pahit \\
Fermentasi 2 hari & $66,1 \mathrm{a}$ & Agak pahit \\
Fermentasi 6 hari & $66,6 \mathrm{a}$ & Agak pahit \\
\hline
\end{tabular}

Keterangan : Angka-angka yang diikuti huruf kecil yang sama berbeda tidak nyata menurut uji DNMRT taraf $=\alpha 5 \%$

* : Interpretasi skor Skala Likert 5 skala

Dari Tabel 4 dapat dilihat bahwa kepahitan coklat dengan lama fermentasi 4, 8, 2, 6 hari dan tanpa fermentai menunjukkan hasil berbeda tidak nyata satu sama lainnya. Hasil uji interpretasi skor kala Linkert 5 skala, tingkat kepahitan coklat pada perlakuan fermentasi 6, 2 hari dan tanpa fermentasi menunjukkan kriteria agak pahit, sedangkan perlakuan fermentasi 8 dan 4 hari menunjukkan kriteria pahit.

\section{Kesukaan Coklat}

Kesukaan panelis terhadap mutu coklat ditentukan oleh gabungan dari keseluruhan peubah yang ditentukan dalam penelitian ini. Dari hasil uji DNMRT menunjukkan bahwa dengan lama waktu fermentasi yang berbeda pada biji kakao lindak berpengaruh nyata terhadap kesukaan coklat. Skor nilai cita rasa coklat pada beberapa waktu fermentasi yang berbeda dapat dilihat pada Tabel 5 berikut ini. 
Ridawati Marpaung dan Siti Nurlina Putri. Karakteristik Mutu Organoleptik Olahan Coklat Dengan Lama Fermentasi Yang Berbeda Pada Biji Kakao Lindak (Theobroma Cacao L.)

Tabel 5. Skor nilai kesukaan coklat dengan lama fermentasi yang berbeda.

\begin{tabular}{ccc}
\hline Perlakuan & Skor & Kesukaan Coklat* \\
\hline Tanpa fermentasi & $50,5 \mathrm{a}$ & Agak disukai \\
Fermentasi 2 hari & $53,8 \mathrm{ab}$ & Agak disukai \\
Fermentasi 4 hari & $56,6 \mathrm{abc}$ & Agak disukai \\
Fermentasi 8 hari & $59,9 \mathrm{bc}$ & Agak disukai \\
Fermentasi 6 hari & $64,4 \mathrm{c}$ & Disukai \\
\hline
\end{tabular}

Keterangan : Angka-angka yang diikuti huruf kecil yang sama berbeda tidak nyata menurut uji DNMRT taraf $=\alpha 5 \%$

* : Interpretasi skor Skala Likert 5 skala

Dari Tabel 5 dapat dilihat bahwa cita rasa coklat dengan lama fermentasi 2, 4 hari dan tanpa fermentasi menunjukkan hasil berbeda tidak nyata. Kemudian perlakuan lama fermentasi 2, 4 dan 8 hari juga menunjukkan hasil tidak berbeda nyata satu sama lainnya serta perlakuan fermentasi 4, 8 dan 6 hari menunjukkan hasil berbeda tidak nyata. Sedangkan perlakuan fermentasi 6 hari berbeda nyata dengan tanpa fermentasi. Hasil uji interpretasi skor skala Linkert 5 skala, kesukaan coklat yang disukai panelis yaitu pada perlakuan fermentasi 6 hari, sedangkan fermentasi 2, 4, 8 hari dan tanpa fermentasi menunjukan nilai agak disukai.

\section{Ph Biji Kakao Kering}

Dari hasil analisis DNMRT menunjukan bahwa menunjukan bahwa perlakuan lama fermentasi berpengaruh nyata terhadap nilai $\mathrm{pH}$ biji kakao kering.

Tabel 6. Skor nilai pH coklat dengan lama fermentasi yang berbeda.

$\begin{array}{cc}\text { Perlakuan } & \text { Skor } \\ \text { Tanpa fermentasi } & 5,8 \mathrm{a} \\ \text { Fermentasi } 2 \text { hari } & 5,9 \mathrm{a} \\ \text { Fermentasi 4 hari } & 6,0 \mathrm{a} \\ \text { Fermentasi 6 hari } & 6,6 \mathrm{~b} \\ \text { Fermentasi } 8 \text { hari } & 7,3 \mathrm{c}\end{array}$

Keterangan : Angka-angka yang diikuti huruf kecil yang sama berbeda tidak nyata menurut uji DNMRT taraf $=\alpha 5 \%$

Dari Tabel 6 dapat dilihat bahwa pH biji kakao kering dengan lama fermentasi 2, 4 hari dan tanpa fermentasi menunjukkan hasil berbeda tidak nyata, tetapi berbeda nyata dengan lama fermentasi 6 dan 8 hari.

\section{Analisis Kadar Air}

Dari hasil analisis DNMRT menunjukan bahwa perlakuan lama fermentasi berpengaruh nyata terhadap kadar air biji kakao kering.

Tabel 7. Skor nilai kadar air biji kakao dengan lama fermentasi yang berbeda.

\begin{tabular}{cc}
\hline Perlakuan & Skor \\
\hline Fermentasi 8 hari & $5,5 \mathrm{a}$ \\
Fermentasi 6 hari & $6,0 \mathrm{ab}$ \\
Fermentasi 2 hari & $6,4 \mathrm{abc}$ \\
Fermentasi 4 hari & $6,5 \mathrm{bc}$ \\
Tanpa fermentasi & $7,1 \mathrm{c}$ \\
\hline
\end{tabular}

Keterangan : Angka-angka yang diikuti huruf kecil yang sama berbeda tidak nyata menurut uji DNMRT taraf $=\alpha 5 \%$

Dari Tabel 7 dapat dilihat bahwa kadar air biji kakao kering dengan lama fermentasi 8, 6 dan 2 hari menunjukan hasil berbeda tidak nyata. Perlakuan lama fermentasi 6, 2 dan 4 hari juga menunjukkan hasil 
berbeda tidak nyata satu sama lainnya, tetapi perlakuan lama fermentasi 8 hari berbeda nyata dengan tanpa fermentasi.

\section{Pembahasan}

Fermentasi pada biji kakao merupakan salah satu kegiatan pasca panen yang sangat menentukan kualitas bubuk coklat dan olahannya. Dalam proses fermentasi terjadi perubahan kimia pada biji kakao yaitu terbentuknya komponen prekussor aroma, cita rasa, dan pembentukan warna coklat.

Berdasarkan pengamatan warna olahan coklat, terlihat bahwa dengan lama fermentasi penuh yaitu 6 dan 8 hari menghasilkan warna coklat, sedangkan perlakuan lainnya menunjukkan hasil warna coklat kehitaman. Hal ini sejalan dengan pendapat Siregar dkk (1989) dalam Nursalam (2005), bahwa biji kakao yang difermentasi secara penuh ditandai dengan warna coklat hingga coklat tua. Menurut Widyotomo (2004), faktor yang berperan dalam pembentukan warna adalah proses fermentasi, karena dalam proses fermentasi yang penuh terjadi penguraian senyawa polifenol. Kandungan polifenol dalam biji akan mendorong reaksi maillard dengan bantuan polifenol oksidasi menghasilkan warna coklat.

Warna coklat kehitaman pada coklat adalah karena terjadinya reaksi maillard pada saat penyangraian pada biji kakao, reaksi maillard ini mengakibatkan reaksi secara non-enzimatis yaitu reaksi antara senyawa hidrokarbon (gula pereduksi) dengan gugus amin bebas dan asam amino atau protein. Reaksi inilah yang menimbulkan perubahan pada warna pada coklat (Sirossiris, 2011).

Aroma merupakan faktor terpenting bagi konsumen dalam memilih produk makanan yang disukai. Menurut Winarno (1993), bahwa banyak hal kelezatan makanan yang ditentukan oleh aroma makanan tersebut. Tingkat kesukaan terhadap aroma yang dihasilkan tertinggi pada coklat adalah pada perlakuan lama fermentasi 6 dan 8 hari dan terendah terdapat pada perlakuan tanpa fermentasi. Hal ini diduga pada fermentasi 6 dan 8 hari aroma khas coklat akan mucul sedangkan tanpa fermentasi aroma khas dari coklat tidak muncul.

Komponen aroma biji kakao terdiri dari senyawa volatile yang terutama terbentuk dari reaksi gugus amino dan karboksil. Kedua senyawa tersebut hasil perombakan peptida dan karbohidrat yang berlangsung selama fermentasi. Senyawa pembentuk aroma khas biji kakao terdiri dari asam-asam hidropobik, peptida hidropobik dan gula pereduksi. Waktu fermentasi berpengaruh terhadap aroma yang dihasilkan, semakin lama fermentasi aroma khas biji kakao semakin kuat (Mulato dan Widyatomo, 2003).

Menurut Mulato (2002), senyawa volatile furan, senyawa fenol dapat menimbulkan aroma pada coklat. Selain itu juga komponen pirazin merupakan komponen aroma yang terbentuk akibat penyangraian pada biji kakao, jumlah komponen pirazin yang dihasilkan ditentukan oleh komposisi komponen prekussor seperti asam amino bebas, peptide, dan gula secara enzimatis terbentuk dalam proses fermentasi. Selain senyawa fenol dan pirazin terdapat juga senyawa benzene yang terbentuk selama penyangraian yang merupakan senyawa golongan aromatik yang berbau sedap seperti aroma kacang.

Dari hasil uji organoleptik, penilaian cita rasa tertinggi pada coklat terdapat pada perlakuan lama fermentasi 6 hari dengan nilai 68,8 dan 8 hari dengan nilai 61,6 serta terendah pada perlakuan fermentasi 4 hari dengan nilai 49,9.

Fermentasi dimaksudkan untuk menumbuhkan cita rasa yang baik karena selama fermentasi terjadi penguraian senyawa polifenol, protein dan gula oleh enzim yang menghasilkan senyawa calon rasa. Dengan fermentasi yang sempurna senyawa-senyawa tersebut semakin banyak yang terurai ( Widyotomo, 2001).

Komponen cita rasa khas selanjutnya akan terbentuk selama penyangraian (roasting). Selama penyangraian senyawa-senyawa pembentuk cita rasa bereaksi satu sama lainnya melalui reaksi maillard, kemudian menghasilkan komponen-kompenen yang mudah menguap dan beraroma khas coklat seperti golongan alkohol, ester, furan, tiazol, pirazin dan perol ( Misnawi, 2005).

Tujuan dari fermentasi biji kakao lindak adalah mengurangi rasa pahit pada coklat, tetapi dari hasil uji organoleptik kepahitan menunjukkan bahwa fermentasi 6 hari, 2 hari dan tanpa fermentasi menunjukan nilai 66,6, 66,1 dan 64,9 dengan kriteria agak pahit sedangkan fermentasi 8 hari dan 4 hari menunjukkan nilai 55,5 dan 56,6 dengan kriteria pahit. Hal ini disebabkan oleh panelis yang kurang terlatih sehingga persepsi dari panelis kurang akurat tentang tingkat kepahitan coklat. 
Salah satu faktor yang mempengaruhi tingkat kepahitan biji kakao adalah senyawa polifenol yang terdiri dari antosianin, leokuantosianin, katekin, polifenol kompleks kemudian polifenol teroksidasi membentuk quinon dan diquinon. Selama proses fermentasi aktivitas enzim menghidrolisis polifenol. Polifenol adalah senyawa yang menimbulkan rasa sepat pada coklat (Mulato, 2002).

Hasil analisis organoleptik dan analisis DNMRT, tingkat kesukaan panelis terhadap coklat merupakan gabungan dari semua peubah organoleptik yang diamati. Tingkat kesukaan panelis tertinggi terdapat pada perlakuan lama fermentasi 6 hari dengan nilai 64,4. Panelis menyukai coklat yang difermentasi 6 hari karena coklat yang dihasilkan memiliki warna coklat, aroma disukai, cita rasa disukai, dan tingkat kepahitan agak pahit.

Hasil analisis DNMRT, menunjukkan perbedaan nilai $\mathrm{pH}$ pada biji kakao kering menunjukkan ada perbedaan warna biji kakao. pH biji kakao yang difermentasi cenderung mendekati netral yaitu 6,0 6,6 dan 7,3. Biji yang tidak difermentasi mempunyai $\mathrm{pH}$ lebih rendah, cenderung memberikan warna yang lebih terang dari biji yang difermentasi. Pada $\mathrm{pH}$ yang mendekati netral senyawa-senyawa aroma khas coklat terbentuk dengan intensif. Sedangkan pada $\mathrm{pH}$ yang lebih rendah, pembentukan aroma coklat sangat terbatas. Keasaman biji kakao juga memberikan cita rasa terhadap produk akhir, karena keasaman yang lebih tinggi meninggalkan rasa asam yang tidak disukai.

Keasaman biji meningkat pada awal fermentasi hingga hari ketiga, hal ini terjadi karena terjadi difusi asam ke dalam biji. Setelah hari ketiga nilai keasaman menurun karena asam terurai dan aroma terbentuk, sehingga lama fermentasi berpengaruh terhadap keasaman biji kakao (Soerotani, 2010).

Dari hasil penelitian perlakuan fermentasi 8 hari, 6 hari, 4 hari, 2 hari, dan tanpa fermentasi, biji kakao tidak ada yang berkecambah. Hal ini terjadi karena di dalam proses fermentasi selain bertujuan untuk membentuk cita rasa, proses fermentasi juga akan mematikan biji kakao. Hal ini disebabkan karena suatu proses produk energi di dalam sel yang tanpa melibatkan oksigen atau disebut juga anaerobik. Keberadaan asam sitrat yang dihasilkan dalam proses fermentasi membuat lingkungan pulp menjadi asam sehingga akan menginisiasi pertumbuhan ragi dan terjadi fermentasi secara anaerobik. Selain fermentasi anaerobik juga terjadi fermentasi aerobik yang diinisiasi oleh bakteri asam laktat dan bakteri asam asetat. Jadi produk fermentasi yang dihasilkan yaitu berupa etanol, asam laktat, dan asam asetat yang akan berdifusi ke dalam biji dan membuat biji tidak berkecambah.

Dari hasil analisis DNMRT, kadar air biji kakao kering dengan perlakuan fermentasi 8 hari menunjukkan hasil terendah yaitu 5,5, sedangkan nilai kadar air tertinggi yaitu pada perlakuan tanpa fermentasi dengan nilai 7,1 .

Menurut Widya (2003), kadar air yang tinggi pada akhir proses fermentasi ( \pm k.a $60 \%$ ), harus diturunkan menjadi sekitar 6-7\% sebelum biji kakao diolah lebih lanjut. Hal ini dilakukan agar pada biji kakao tidak mudah tumbuh kapang maupun jamur sehingga dapat mengurangi kualitas dari biji kakao itu. Namun apabila pengeringan berlangsung sampai pada kadar air dibawah 6\% maka biji kakao akan mudah hancur, kalitas rasa dan aroma juga akan menurun. Semakin lama fermentasi maka kadar air biji kakao yang dihasilkan semakin rendah. Penurunan kadar air terjadi karena semakin lama fermentasi menyebabkan aktivitas mikroba semakin meningkat dan aktivitas enzim lebih aktif. Reaksi ini menghasilkan panas selama proses fermentasi sehingga pulp menjadi encer dan menyebabkan jaringan kompleks dalam biji kakao terdegradasi dalam bentuk senyawa organik yang lebih sederhana. Selain itu selama proses fermentasi akan terjadi kematian biji yang mengakibatkan sifat semi-permeabilitas dinding sel menjadi rusak, sehingga dapat memudahkan keluarnya air selama proses fermentasi.

Fermentasi merupakan inti dari proses pengolahan biji kakao lindak yang bertujuan untuk memperbaiki cita rasa, aroma, warna coklat dan keasaman. Selain itu, fermentasi menyebabkan terjadi perubahan-perubahan senyawa kimia di dalam biji. Apabila fermentasi dilakukan dengan baik dan sempurna, maka dapat meningkatkan kualitas coklat yang dihasilkan. Selain itu juga fermentasi menyebabkan berkurangnya polifenol terlarut sehingga terjadi pengurangan atau pengeluaran theobromin dan kafein serta komponen-komponen volatil (alkohol, ester, dan aldehid) (Mulato dan Widyatomo, 2003). 


\section{KESIMPULAN}

Berdasarkan hasil penelitian dan pembahasan dapat ditarik kesimpulan bahwa lama fermentasi yang berbeda berpengaruh nyata terhadap mutu organoleptik dan fisik seperti warna, aroma, cita rasa, kesukaan, pH dan kadar air biji kakao kering, tetapi berbeda tidak nyata terhadap kepahitan. Penilaian tertinggi terhadap warna, aroma, cita rasa, kepahitan dan kesukaan terdapat pada perlakuan lama fermentasi 6 hari dan 8 hari.

\section{DAFTAR PUSTAKA}

Abdullah, 2005.Pengujian Organoleptik Dalam Industri Pangan http ://tekpan. Unimus.ac.id/wpcontent/uploads/2013/07/Pengujian-Organoleptik-dalam-Industri-Pangan.pdf

Afriansyah, 2005. Pengujian Organoleptik (online) Coklat http:// repo.iain-pengujianorganoleptik.ac.id/4523/

Agung, 2013. Cara Budidaya Tanaman Kakao Indonesia ( online ) http://tipsbudidaya.blogspot.com/2009/03/budidaya-kakao.html

Andarti dan Wardani, 2015. Karakteristik Fisik dan Kimia Coklat Jahe. Balai Pustaka Utama. Jakarta.

Astuti, 2007. Petunjuk Praktikum Analisis Bahan Biologi. Yogyakarta : Jurdik Biologi FMIPA UNY

Belitz, 2009. Pengaruh Cara Pengolahan Kakao Fermentasi dan Non Fermentasi Terhadap Kualitas, Harga Jual Produk pada Unit Usaha Produktif(UUP) Tunjung Sari, Kabupaten Tabanan. https:/ /media.neliti.com /media/ publi cations/44956-ID-pengaruh-cara-pengolahan-kakao-fermentasi-dannon-fermentasi-terhadap-kualitas-h.pdf

Cardelli, 2001. Sifat Kimia Dan Evaluasi Sensorik Aneka Produk Coklat http:// repo.iain-sifat-kimia-danevaluasi-sensorik-aneka-produk-coklat.ac.id/4523/

4/BAB\%20III.pdf

Clifford, 2012. Teknologi Kepahitan Coklat. Gajah Mada University Press. Yogyakarta.

Darmawa, 2013. Biji Kakao Pasca Panen di Fermentasi Dalam Peti. (online) https :// postharvestnotes. wordpress.com/2015/07/01/fermentasi-kakao/ diakses tanggal 23 April 2018.

Direktorat Jenderal Perkebunan, 2017. Statistik Perkebunan Indonesia 2015 - 2017 (online) http : // ditjenbun . pertanian .go.id/ tinymcpuk /gambar/file/ statistik /2017/Buku-Kakao-2015-2017.pdf

Dinas Perkebunan Provinsi Jambi, 2015. Luas dan Lahan Produksi Tanaman Menurut Jenis Tanaman. (online) https :// repository.ipb.ac.id /jspui/bitstream /123456789/67397/1/2013 cre .pdf

Febrianto, 2009. Fermentasi Biji Kakao Untuk Menghilangkan Rasa Sepat Pahit https://unsurtani.com/2017/10/fermentasi-biji-kakao-untuk-memperbaiki-cita-rasa-dan-mengurangirasa-sepat-pahit

Gevan, 2009. Pengolahan Biji Kakao. (online) https:// guesty.wordpress.com /2009/ 01/28 /pengolahanbiji-kakao/

Indrayati, 2013. Fermentasi Biji Kakao untuk Menghasilkan Cokelat Berkualitas https : // www. kompasiana. com/sriindrayati/ 552a9b876 ea $8341 \mathrm{f} 62552 \mathrm{~d} 3$ a/fermentasi-biji-kakao-untukmenghasilkan-cokelat-berkualitas

Leroy, 2006. Pengolahan Biji Kakao Menjadi Coklat (online) http://coklatchocolate.blogspot.com/2008/03/proses-pengolahan-biji-kakaomenjadi.html

Mulato, 2002. Penilaian Organoleptik Untuk Industri Pangan dan Hasil Pertanian. Barata Karya Aksara. Jakarta.

Nasution, dkk. 1985. Analisis Biji Kakao Dan Pengolahan (online) https:// www.kompasiana.com /112/550 aed7aa333119d712e3c99/

Nugraha, 2017. Budidaya Kakao (online) http://agrindonesia.wordpress.com /2009/04/15/budidayakakaocoklat/

Nuraeni, 2011. Mutu Biji Kakao. https :// media. neliti. com/ media /publications/ 151561-ID-mutu-bijikakao.pdf 
Ridawati Marpaung dan Siti Nurlina Putri. Karakteristik Mutu Organoleptik Olahan Coklat Dengan Lama Fermentasi Yang Berbeda Pada Biji Kakao Lindak (Theobroma Cacao L.)

Nursalam, 2005. Pengaruh Fermentasi Biji Kakao Terhadap Olahan coklat (online) https://media.neliti.com/media/publications/93872-ID-pengaruh-fermentas-biji-kakao-terhadapolahan-coklat.pdf

Pairunan, 2009. Menyimak Proses Fermentasi Kakao. http://sudut-bacaan. Blogspot .com /2013/05/ menyimak-proses-fermentasi-kakao.html

Prayoga, 2013. Penanganan Pasca Panen Kakao. https:// www. kompasiana.com /fathan112/550 aed7aa333119d712e3c99/ penanganan-pasca-panen-kakao

Putra, 2013. Standar Mutu Biji Kakao di Indonesia. Proc. Konp. Nas. Kakao III, https://multimeterdigital.com/standar-mutu-biji-kakao-cokelat.html

Putri, 2011). Uji Organoleptik Produk Permen Coklat Dengan Variasi Penambahan Virgin Coconut Oil (VCO) https :// www.stppmedan .ac.id/pdf/ Jurnal\% 20 Vol \%2 011-2/005\%Putri.pdf

Rahardi, 2011. Pengolahan Biji Kakao. (online) https :// viber. Wordpress .com /budidaya - kakao/ pengolahan -kakao/

Ramlah, S, 2016. Karakteristik Mutu Dan Cita Rasa Coklat Kaya Folifenol. (online) https:// www.kompasiana.com /112/550 aed7aa333119d712e3c99/ karakteristik-mutu-dan-citarasa-coklatkaya-folenol.

Santoso, 2015. Teknik Budidaya Lengkap. (online) https :// seputarpertanian oke. blogspot.com/2015/09/teknik-budidaya-tanaman-kakao-lengkap.html

Sirossiris, 2011. Karakteristik Kimia Coklat Pasta Dan Batangan. Balai Pustaka Utama. Jakarta.

Suheri, 2010. Teknik Fermentasi Dalam Pengolahan Biji Kakao. https:// disbun lambar. wordpress.com/ about/ tehnik-fermentasi-dalam-pengolahan-biji-kakao/

Soerotani, 2010. Teknologi Industri Pertanian Pengolahan Biji Kakao. http : // soerotani. blogspot.com /2010/07/teknologi-industri-pertanian-pengolahan-biji-kakao.html

Suryani, 2013. Perkembangan dan Prospek Kakao Dunia dan Kepentingan Indonesia. (online) http ://www. Data con .co. id/-Agri2013 kakao.html.

Susanto, 2007. Pengolahan Biji Kakao (online) https ://789. wordpress.com /2016/02/19/ pengolahan-bijikakao/

Syadiah, 2014. Pengertian Manfaat Proses Fermentasi. http://adetiyapolije .wordpress .com /2008 /04/08/ fermentasi-biji-kakao/

Widyotomo, 2013. Penanganan Pasca Panen Biji Kakao Lama Fermentasi dan Hasil Pengeringan. http://www.reseachgate.net.

Widya, 2003. Penyimpan, Pengeringan Dan Sortasi Biji Kakao Dan Kopi https://www.scribd.com/doc/135890569/Artikel-Penyimpanan-Pengeringan-Dan-Sortasi-Kakao-

Dan-Kopi

Yuono, 2015. Teknik panen buah kakao yang baik. (online) https:// alamtani.com/ panen-buah - kakao/ 